\title{
A Rare Case of Posterior Knee Pain: Synovial Osteochondramatosis
}

\author{
Nadir Bir Diz Arkası Ağrı Sebebi Olgusu: Sinovyal Osteokondromatozis \\ (1) Berke Aras, (1) Ömer Kuzu, (1) Serdar Kesikburun*, (1) Evren Yaşar* \\ Kastamonu Physical Therapy and Rehabilitation Center, Clinic of Physical Medicine and Rehabilitation, Kastamonu, Turkey \\ *University of Health Sciences Turkey, Gaziler Physical Therapy and Rehabilitation Training and Research Hospital, Clinic of Physical Medicine and \\ Rehabilitation, Ankara, Turkey
}

\section{Abstract}

Synovial osteochondromatosis (SOC) is an uncommon benign condition characterized by the proliferation of the synovium with cartilaginous metaplasia. It can develop in any joint where synovium exists but is most prevalent in the knee. It generally occurs in the knee's anterior compartment, but it can also be seen in the posterior fossa. In this article, we report a 58-year-old woman with knee pain and swelling secondary to SOC. The detection of calcific nodules in both plain radiography and magnetic resonance imaging of the knee determined the diagnosis. SOC needs attention due to its high morbidity rates and possibility of malignant transformation.

Keywords: Osteochondromatosis, knee pain, synovium

\section{Öz}

Sinovyal osteokondromatozis (SOC) sinovyumun kıkırdaksı metaplazisi ile proliferasyonu ile karakterize benign nadir bir durumdur. SOC sinovyumun olduğu herhangi bir eklemde görülmesine rağmen en sık dizde görülür. Genellikle dizin ön kompartımanında görülse de posterior fossada da görülebilmektedir. Bu olguda, SOC nedeniyle dizde ağrı ve şişlik şikayetleri bulunan 58 yaşında kadın bir hasta sunulmuştur. Direkt radyografi ve manyetik rezonans görüntülemede kalsifik nodüllerin görülmesi tanıyı desteklemiştir. SOC yüksek morbidite oranı ve malign transformasyon intimali nedeniyle ayrıca dikkat edilmesi gereken bir durumdur.

Anahtar kelimeler: Osteokondromatozis, diz ağrısı, sinovyum

\section{Introduction}

Synovial chondromatosis is a rare idiopathic disease affecting the synovial joints, tendon sheaths and bursa (1). It has been estimated an incidence of one case for 100,000 people (2). It is characterized by multiple cartilage foci and metaplasia formation in the intima layer of the synovial membrane of the joint. Multiple and cartilaginous nodules are formed in the synovium because of that the nodules formed in the synovial membrane of the joint break off and become free (3). The term synovial osteochondromatosis is used in cases where the cartilage lesion is ossified. Although the etiology is unknown, it is thought that it may develop as a result of synovial irritation due to trauma or infection.

There are two forms of synovial osteochondromatosis. Primary synovial osteochondromatosis is almost always monoarticular and involves large joints, especially the knee. The diagnosis is determined generally between $3^{\text {rd }} 5^{\text {th }}$ decades of life and is more common in males. The more common secondary form is seen in older age and after pathologies such as trauma, osteoarthritis, osteochondritis dissecans or neuropathic arthropathy (4).

Although non-steroidal anti-inflammatory drugs reduce symptoms, surgery is often preferred for the treatment of synovial osteochondromatosis. Due to the relapse of the disease and malignant degeneration, complete resection of the involved synovium is necessary as well as removal of free intraarticular bodies (5).

In this case report, a patient diagnosed as synovial osteochondromatosis is presented.

\section{Case Report}

A 58-year-old female patient was referred to our outpatient clinic with complaints of pain and swelling in the posterior aspect of her left knee for six months. Her symptoms relieved when using non-steroidal anti-inflammatory drugs (asemetazine, diclofenac), however the symptoms repeated

Address for Correspondence/Yazışma Adresi: Berke Aras MD, Kastamonu Physical Therapy and Rehabilitation Center, Clinic of Physical Medicine and Rehabilitation, Kastamonu, Turkey

Phone: +90 3662144331 E-mail: drberkearas@gmail.com ORCID ID: orcid.org/0000-0002-2761-3478 Received/Geliş Tarihi: 30.06.2020 Accepted/Kabul Tarihi: 05.08.2020

${ }^{\circ}$ Copyright 2021 by the Turkish Osteoporosis Society / Turkish Journal of Osteoporosis published by Galenos Publishing House 
when she ceased the medications. There was no prior trauma or any known knee disease. Physical examination revealed a swelling in the posterior of the left knee. There was no range of motion limitation and redness in the knee joint. The patient reported a pain intensity of 8 on the $10-\mathrm{cm}$ visual analogue scale. No abnormal finding was seen in blood tests. X-ray showed narrowing of the joint space, osteophytes and irregular calcified nodular opacities in the popliteal fossa (Figure 1). Hypointense nodular lesions were detected in the popliteal fossa in T2 sequences by magnetic resonance imaging (MRI) (Figure 2). The images were consistent with synovial osteochondroma of the knee joint. The patient was referred to the orthopedics clinic for surgery. Written consent was taken from patient.

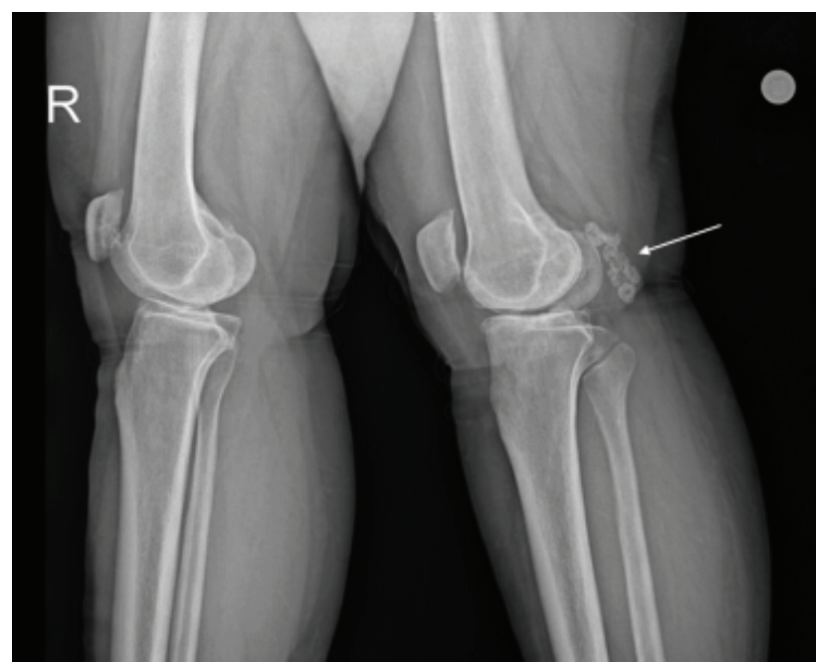

Figure 1. Lateral direck radiography of the left knee showed irregular calcified nodular opacities in the popliteal fossa

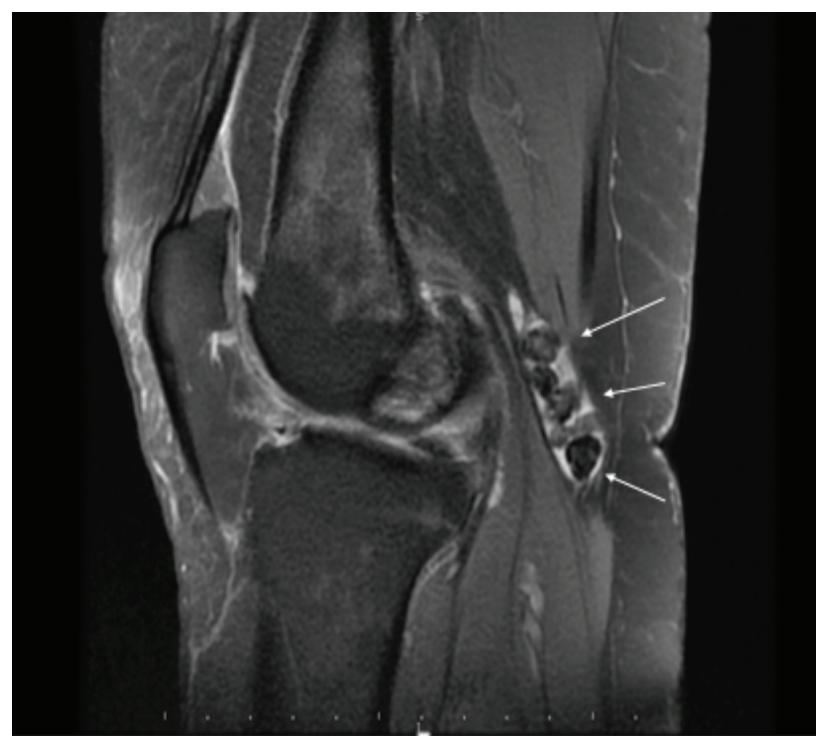

Figure 2. Knee magnetic resonance imaging with sagittal T2 sequences demonstrate hypointense nodular lesions in the popliteal fossa

\section{Discussion}

Although synovial osteochondromatosis can develop in any joint where synovium exists, it is most prevalent in the knee (5). It is reported to be detected in the elbow, ankle, hip and shoulder joints after the knee joint. It has rarely been shown to involve small joints (6). The disease generally occurs in the anterior compartment of the knee such as the suprapatellar pouch, infrapatellar fat pad and medial-lateral gutter $(7,8)$. In the present case, it was seen that the disease appeared in the posterior fossa in the posterior compartment of the knee.

The disease process is insidious and the diagnosis can be made years later (9). Clinically, patients with synovial osteochondromatosis have progressively increased joint pain and swelling. Joint pain is associated with damage to the joint surface, which may lead to joint locking and instability over time $(10,11)$. The patient in this case had joint pain and swelling that persisted for six months, increased over time, and responded positively to non-steroidal anti-inflammatory drugs, but there was no limitation of joint mobility and locking feel because of the posterior localization of the calcific nodules. The patient's advanced age, degenerative changes in the joints and no history of trauma or infection suggest the diagnosis of secondary synovial osteochondromatosis.

The pathogenesis of the disease involves a metaplastic error of synovial cells. Chondroid bodies usually appear at the ends of the synovial villi. The cells surrounding the bodies turn into chondroblasts. These cartilage clusters grow in the form of spherical bodies connected to the vilus with their pedicles: Later, these cartilage clusters can separate from the pedicles and fall into the joint and form loose bodies. These loose bodies feed on synovial fluid and continue to grow. With the emergence of osteoblasts, cellular metaplasia occurs and bone nidus may occur (7).

Diagnosis of synovial osteochondramatosis can be difficult especially in the early chondromatosis stage and calcified formations within the joint may be radiologically confused with degenerative osteoarthritis, osteochondritis dissecans, pigmented villonodular synovitis, neuropathic arthropathy and gout. Direct radiography is important for the diagnosis of calcific nodules, but in 5-30\% of cases it cannot be diagnosed because the nodules are not calcified yet (12). MRI is the most useful test in the early diagnosis of the disease. MRI supports the diagnosis of non-calcified nodules as well as detecting changes in joint and bone structures adjacent to the lesion (12). It also distinguishes the disease from other diseases associated with synovial proliferation, such as synovial hemangioma, synovial sarcoma and pigmented villonodular synovitis. In this case, since the nodules were calcific, both plain radiography and MRI supported the diagnosis of synovial osteochondramtosis.

Surgery is the most commonly used method in the treatment of synovial osteochondromatosis. Recurrence and malignant degeneration may be seen, although not frequent. Therefore, no chondromatosis focus should be left in the joint during surgical 
treatment. In this regard, cases that underwent synovectomy due to synovial osteochondromatosis and residual cartilage lesions that grow into chondrosarcoma have been reported (13). Therefore, the patient should be followed up at certain times after the operation for recurrence. Non-steroidal antiinflammatory drugs and physical therapy agents have been used to reduce symptoms if patients do not accept the operation (14). The patient in this case stated that using non-steroidal antiinflammatory drugs for a long time reduced his symptoms.

Synovial osteochondromatosis may cause complications such as osteoarthritis, nerve entrapment, tendon tear, malignant transformation and patellar subluxation when not treated (1517). In the study of Biazzo and Confalonieri (18), it was found that $67.1 \%$ of synovial osteosarcomas originated from synovial osteochondromatosis and the mean tumor formation time was 11.2 years.

Synovial osteochondromatosis is a rare pathology involving the knee joint. The disorder should be kept in mind in the differential diagnosis of knee pain.

\section{Ethics}

Informed Consent: Written consent was taken from patient. Peer-review: Externally peer-reviewed.

\section{Authorship Contributions}

Surgical and Medical Practices: B.A., Ö.K., Concept: B.A., S.K., Design: B.A., Ö.K., S.K., Data Collection or Processing: Ö.K., E.Y. Analysis or Interpretation: B.A., E.Y., Literature Search: B.A., Ö.K., S.K., Writing: B.A., E.Y.

Conflict of Interest: No conflict of interest was declared by the authors

Financial Disclosure: The authors declared that this study received no financial support.

\section{References}

1. Milgram JW. Synovial osteochondromatosis: a histopathological study of thirty cases. J Bone Joint Surg Am 1977;59:792-801.

2. Osti L, Papalia R, Del Buono A, Denaro V, Maffulli N. Recurrence of synovial chondromatosis of the Hoffa's body. Knee Surg Sports Traumatol Arthrosc 2009;17:1421-4.
3. Ackerman D, Lett P, Galat DD Jr, Parvizi J, Stuart MJ. Results of total hip and total knee arthroplasties in patients with synovial chondromatosis. J Arthroplasty 2008;23:395-400.

4. Hamada J, Tamai K, Koguchi Y, Ono W, Saotome K. Case report: A rare condition of secondary synovial osteochondromatosis of the shoulder joint in a young female patient. J Shoulder Elbow Surg 2005; 14:653-6.

5. Davis RI, Hamilton A, Biggart JD. Primary synovial chondromatosis: a clinicopathologic review and assessment of malignant potential. Hum Pathol 1998;29:683-8.

6. Maurice $\mathrm{H}$, Crone M, Watt I. Synovial chondromatosis. J Bone Joint Surg $\mathrm{Br}$ 1988;70:807-11.

7. Karsan O, Yanar HH, Alparslan B. Synovial osteochondromatosis of the knee A report of two cases. Acta Orthop Traumatal Turc 1997;31:265-8

8. Bozkurt M, Uğurlu M, Doğan M, Tosun N. Synovial chondromatosis of four compartments of the knee: medial and lateral tibiofemoral spaces, patellofemoral joint and proximal tibiofibular joint. Knee Surg Sports Traumatol Arthrosc 2007;15:753-5.

9. Sato J, Segami N, Suzuki T, Yoshitake Y, Nishikawa K. The expression of fibroblast growth factor-2 and fibroblast growth factor receptor-1 in chondrocytes in synovial chondromatosis of the temporomandibular joint. report of two cases. Int J Oral Maxillofac Surg 2002;31:532-6.

10. Taylor JA, Hughes TH, Resnick D. Introduction to skeletal disorders. In: Skeletal Imaging Atlas of The Spine and Extremities. 2nd ed. Saunders Elsevier; 2010. p. 1-43.

11. Khan Z, Yousri T, Chakrabarti D, Awasthi R, Ashok N. Primary synovial osteochondromatosis of the first metatarsophalangeal joint, literature review of a rare presentation and a case report. Foot Ankle Surg 2010;16:1-3.

12. Fujita I, Matsumoto K, Maeda M, Kizaki T, Okada Y, Yamamoto T. Synovial osteochondromatosis of the Lisfranc joint: a case report. J Foot Ankle Surg 2006;45:47-51.

13. Milgram JW, Addison RG. Synovial osteochondromatosis of the knee. Chondromatous recurrence with possible chondrosarcomatous degeneration. J Bone Joint Surg Am 1976;58:264-6.

14. Tastaban E, Turan Y, Yıldırım C, Sendur OF. Knee Joint Synovial Osteochondromatosis: case. Turk J Phys Med Rehab 2014;60:76-9.

15. Neumann JA, Garrigues GE. Synovial chondromatosis of the subacromial bursa causing a bursal-sided rotator cuff tear. Case Rep Orthop 2015;2015:259483.

16. Butt SH, Muthukumar T, Cassar-Pullicino VN, Mangham DC. Primary synovial osteochondromatosis presenting as constrictive capsulitis. Skeletal Radiol 2005;34:707-13.

17. Bashaireh KM. Patellar Subluxation With Early-Phase Synovial Chondromatosis of the Knee. Orthopedics 2016;39:176-9.

18. Biazzo A, Confalonieri N. Synovial chondrosarcoma. Ann Transl Med 2016;4:280 